Original Article

\title{
PHARMACOKINETICS, HEMATOLOGICAL AND BIOCHEMICAL EFFECTS OF CIPROFLOXACIN HYDROCHLORIDE-SODIUM CHOLATE COMPLEX
}

\author{
OSONWA U. E. ${ }^{1}$, UGOCHUKWU J. I. ${ }^{2}$, ONYEGBULE F. A. ${ }^{*}{ }^{3}$, ESIMONE C. $0{ }^{2}$
}

1Department of Pharmaceutics and Pharmaceutical Technology, ${ }^{2}$ Department of Pharmaceutical Microbiology and Biotechnology, ${ }^{3}$ Department of Pharmaceutical and Medicinal Chemistry, Faculty of Pharmaceutical Sciences, Nnamdi Azikiwe University, Awka Nigeria Email: af.onyegbule@gmail.com

Received: 19 Jan 2016 Revised and Accepted: 12 Aug 2016

\begin{abstract}
Objective: Ciprofloxacin is a broad spectrum antibiotic widely used in the treatment of infections, but its toxicological effects remains a great challenge. This research emphasized on analyzing the effect of a hydrophobic ion pair complex, involving ciprofloxacin hydrochloride and sodium cholate and also pegylated ciprofloxacin hydrochloride-sodium cholate complex.

Methods: The effects of ciprofloxacin-cholate complex and pegylated ciprofloxacin-cholate complex were evaluated. $\mathrm{LD}_{50}$ was determined. The test drugs were orally to twenty-four albino mice, in six groups of four mice, at different doses of $7.14 \mathrm{mg} / \mathrm{kg}, 14.2 \mathrm{mg} / \mathrm{kg}$ and $21.4 \mathrm{mg} / \mathrm{kg}$; and PEG complex, 7.14 and $14.2 \mathrm{mg} / \mathrm{kg}$. Each was administered twice daily for fourteen days. The animal blood samples were subjected to hematological, biochemical tests; and the liver organs were collected. Histopathological examination was carried out on the harvested organs. Pharmacokinetic parameters were determined using the non-compartmental method.
\end{abstract}

Results: The $\mathrm{LD}_{50}$ of the complex was above $5000 \mathrm{mg} / \mathrm{kg}$. The non-significant decrease in PCV and WBC showed the parent drug and its complex are neither anemia inducing nor immunosuppressing; the significant decrease in the average RBCs count in post-treatment of $21.47 \mathrm{mg} / \mathrm{kg}$ of the complex could be from physiological changes; the bio-liver makers showed hepatocellular damage. Photomicrograph of the liver sections of mice showed mild areas of hepatocyte degeneration and inflammatory cell infiltrates.

Conclusion: The biochemical, hematological and histology results showed complexation did not increase adverse effects of ciprofloxacin. The PEGYlated complex showed higher AUC and $\mathrm{C}_{\max }$ peak than the uncomplexed drug, hence more therapeutic benefits.

Keywords: PEGY lated, Hepatocellular, Pharmacokinetics, Immunosuppressant, Ciprofloxacin hydrochloride, Cholate complex

(C) 2016 The Authors. Published by Innovare Academic Sciences Pvt Ltd. This is an open access article under the CC BY license (http://creativecommons. org/licenses/by/4. 0/)

DOI: http://dx.doi.org/10.22159/ijpps.2016v8i10.10802

\section{INTRODUCTION}

Ciprofloxacin is a broad-spectrum antibacterial second generational class of fluoroquinolones that is widely used in the treatment of serious infections in higher animals [1]. Its chemical structure is given by (1-cyclopropyl-6-fluoro-1, 4-dihydro-4-oxo-7(1-piperacinyl)-3quinoline carboxylic acid).

However, according to Santo and co-workers [2], the use of ciprofloxacin in the treatment of infections is associated with most common adverse effects that include gastrointestinal tract disturbance, central nervous system disorder and hematological system disorder. According to $\{3\}$, Ciprofloxacin in the treatment of infections is associated with the most common adverse effects which include the gastrointestinal tract, central nervous system, and hematological system effects. Experiment using animal models and clinical experience also showed that Ciprofloxacin-induced cardiotoxicity marked by increase QT and QTC interval and prolonged action potential duration. This increases the risk of arrhythmia (tosarde de points). Ciprofloxacin-induced cardiotoxic effect could be associated with blocking cardiac voltage-gated potassium channels particularly the rapid component (IKr) of the delayed rectifier potassium current. Several cases of Ciprofloxacininduced hepatoxicity have also been reported.

These were characterized by extensive hepatocellular necrosis, mixed inflammatory infiltrates and abundant eosinophils in the liver. Elevated liver enzymes which include serum aspartate aminotransferase, alanine aminotransferase, alkaline phosphatase, and gramma-glutamyltransferase and prolong prothrombin time were reported. The hepatotoxic effect of Ciprofloxacin as reported could be due to oxidative stress induced in the liver by Ciprofloxacin through the generation of oxidative radicals leading to depletion of protein content in hepatocytes as a consequence of nucleic acids diminution and DNA damage. This may lead to significant decrease in the number and degeneration in mitochondria which is responsible for energy supply. Ciprofloxacin-induced cardiotoxicity and hepatotoxicity is relatively low in humans, but patients' liver, and cardiac function may be considered before Ciprofloxacin use. According to $\{4\}$, Ciprofloxacin decreased the sperm concentration, mortality, viability. These suggest that ciprofloxacin has potential toxicological effects on the reproductive system in male rats by decreased sperm count, mortality, increase apoptotic cells and pathological testis.

Ciprofloxacin complexes with surfactant-based-ionic complex have led to a reduction in therapeutic dose [5]. This reduction in dose with its attendant therapeutic and toxicological advantage could be lost due to the possible inability of crossing the stomach barrier to the target site. Hence these complexes require some modifications using polyethylene glycol to get to the targeted site. Polyethylene glycol (PEG), also known as polyethylene oxide (PEO) or polyoxyethylene (POE), depending on its molecular weight, has low toxicity in the system. Its chemical structure is $\mathrm{H}-\left(\mathrm{O}-\mathrm{CH}_{2}-\mathrm{CH}_{2}\right) \mathrm{n}-\mathrm{OH}$. PEG alters solubility, thermal stability, immunogenicity and body residence time. This alteration may be an advantage in making biologically active protein suitable for therapeutic use through modification of pharmacokinetics and pharmacodynamics properties, such as prolongation of half-life in vivo or inhibition of degradation by proteases [6].

This study focuses on the formation of ciprofloxacin-cholate complex and modifying the ciprofloxacin complex by conjugate chemistry, binding inert molecules such as PEG to ciprofloxacin cholate complex to a prolonged residence in the body and decreased degradation by metabolic enzymes. It also considers toxicological effects of the complex. 


\section{MATERIALS AND METHODS}

Acute toxicity study $\left(\mathrm{LD}_{50}\right)$ of ciprofloxacin-cholate complex was measured using Lork's method [7]

hematological studies of ciprofloxacin and ciprofloxacincholate complex and PEG complex in mice

The experimental animals used for this study were white albino mice and rats of either sex. They were obtained from the Animal Unit of the Faculty of Pharmaceutical Sciences, Nnamdi Azikiwe University, Awka. The animals were housed under standard conditions $25{ }^{\circ} \mathrm{C}+/-1{ }^{\circ} \mathrm{C}$ and $24 \mathrm{~h}$ light/dark cycle. They were fed with standard rodent pellets (Vital feed, Nigeria) and had access to clean drinking water. All experimental animals were in compliance with the National Institute of Health Guide for Care and Used of Laboratory Animals (Pub. No 85-23, revised 1985) [8] were adopted and experiments were examined and approved by the appropriate ethics committee" of the Faculty (Faculty of Pharmaceutical Sciences, Nnamdi Azikiwe University, Awka).

The drugs (ciprofloxacin and cholate complex) were dissolved with distilled water (ciprofloxacin), distilled water $+5 \%$ tween 80 (for cholate complex) and administered orally, according to body weight, to sixteen white albino mice, subdivided into four groups having/containing four mice each. Group 1 the control was given only $10 \mathrm{ml} / \mathrm{kg}$ of distilled water. The test solutions were prepared based on the following doses: group 2 which was given ciprofloxacin, 7. $14 \mathrm{mg} / \mathrm{kg}$; group 3 which was given ciprofloxacincholate complex $7.14 \mathrm{mg} / \mathrm{kg}$ and group 4 was given $21.4 \mathrm{mg} / \mathrm{kg}$. The dose was based on $500 \mathrm{mg} / 70 \mathrm{~kg}$ of body weight of a man. Each was administered twice daily for fourteen days $(2 \mathrm{w})$. Blood samples collected through the pituitary eye region of animals and were subjected to haematological test: haemoglobin $(\mathrm{Hb})$, packed cell volume (PCV), red blood cell (RBC), White blood cell count (WBC) [9], and biochemical hepatic makers: aspartate aminotransferase (AST), alanine aminotransferase (ALT) [10] and alkaline phosphates (ALP) [11]. The blood samples were kept at room temperature for $30 \mathrm{~min}$. Clear serum was separated by centrifuging at $2500 \mathrm{rpm}$ for $10 \mathrm{~min}$ after which the mice were sacrificed.

\section{Histopathological studies}

Thereafter, histopathological examination was carried out on the harvested organ. Tissue sections of the Liver from experimental animals were fixed in $10 \%$ formalin saline and dehydrated in ascending grades of ethanol. Thereafter, the tissues were cleared in chloroform overnight, infiltrated and embedded in molten paraffin wax. The blocks were later trimmed and sectioned at 5-6 $\mu \mathrm{m}$. The sections were deparaffinized in xylene, taken to the water and subsequently stained with Haematoxylin and Eosin ( $\mathrm{H}$ and $\mathrm{E})$ for light microscopy.

Pharmacokinetics studies (Serum Concentration) of ciprofloxacin and ciprofloxacin-cholate complex on rats using bioassay

Twenty-four rats, about $150-250$ g body weight, were starved overnight before drug administration to avoid food-drug interactions. The rats were divided into six groups (A, B, C, D, E, and F) with each group having four rats. Respectively they were administered with $7.1 \mathrm{mg} / \mathrm{kg}$ CIP, $14.2 \mathrm{mg} / \mathrm{kg}$ CIP, $7.1 \mathrm{mg} / \mathrm{kg}$ complex, $14.2 \mathrm{mg} / \mathrm{kg}$ complex, $7.1 \mathrm{mg} / \mathrm{kg}$ complex+PEG, $14.2 \mathrm{mg} / \mathrm{kg}$ complex+PEG, in a single dose intraperitoneally. Samples were collected at sampling time $0 \mathrm{hr}, 0.5 \mathrm{~h}, 1 \mathrm{~h}, 2 \mathrm{~h}, 4 \mathrm{~h}, 6 \mathrm{~h}, 12 \mathrm{~h}, 24 \mathrm{~h}$ and centrifuged for $1000 \mathrm{rpm}$ in $20 \mathrm{~min}$ to obtain serum.

Serial dilution 100, 50, 25, 12.5, 6.25, 3.125, $1.56 \mu \mathrm{g} / \mathrm{ml}$ of standard ciprofloxacin hydrochloride was prepared; $20 \mathrm{ml}$ of molten nutrient agar was inoculated with $0.1 \mathrm{ml}$ of standardized broth culture of Staphylococcus aureus (obtained from Bishop Shanahan Hospital, Nsukka) mixed and poured into a Petri-dish (according to number of sampling time). A well of about $6 \mathrm{~mm}$ was dug in the seeded media plate, and 4 drops of various serum samples were introduced into the well along with the standard concentrations starting from the weakest to the strongest. Each sample was analyzed in triplicate and plates were allowed to stand at room temperature for about $5 \mathrm{~min}$ and incubated for $24 \mathrm{~h}$ at $37{ }^{\circ} \mathrm{C}$. The IZD was measured and exact concentration was extrapolated using the standard curve.

\section{Statistical analysis}

The results were expressed as mean \pm Standard Deviation (SD) of sample replicate and paired t-test was to determine the significance or otherwise of the results obtained.

\section{RESULTS}

The result of the toxicity studies on the ciprofloxacin-cholate complex; effects of the ciprofloxacin-cholate complex on the packed cell volume; red blood cells count; haemoglobin count; white blood cells count; ALT level; AST level; ALP level; albumin level are presented in fig. 1 and tables 1 to 9 respectively. Other results, such as the histopathological result of liver tissue are presented in A2 (in appendices).

\section{Histopathological result of liver tissue}

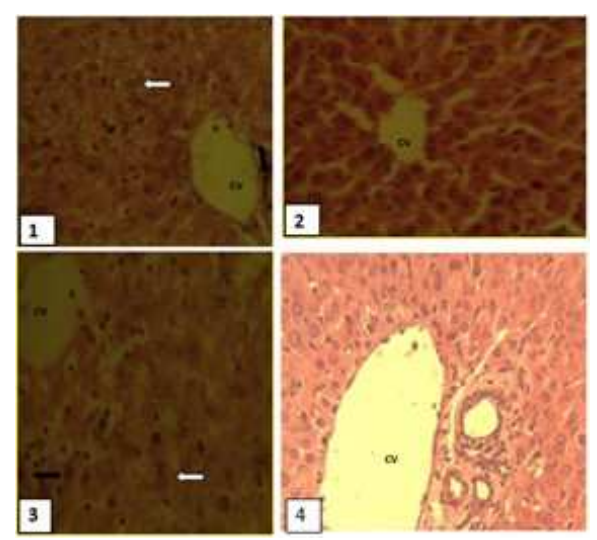

Fig. 1: Photomicrograph of liver sections of mice from experimental groups 1 and 3 showing mild areas of hepatocyte degeneration/vacuolation (white arrows) and inflammatory cell infiltrates (black arrows); that of groups 2 and 4 are apparently normal. Note the central vein (CV). H and E x 400

Table 1: Showing acute toxicity study $\left(\mathrm{LD}_{50}\right)$ of ciprofloxacin-cholate complex on mice

Phase 1

\begin{tabular}{llll}
\hline Group & Dosage & Mice 1 & Mice 2 \\
\hline Group1 & $10 \mathrm{mg} / \mathrm{kg}$ & ND and NST & ND and NST \\
Group2 & $100 \mathrm{mg} / \mathrm{kg}$ & ND and NST & ND and NST \\
Group3 & $1000 \mathrm{mg} / \mathrm{kg}$ & ND and NST & ND and NST \\
\hline
\end{tabular}

Phase 2

\begin{tabular}{|c|c|c|c|c|}
\hline Group & Dosage & Mice 1 & Mice 2 & Mice 3 \\
\hline Group1 & $2000 \mathrm{mg} / \mathrm{kg}$ & ND and NST & ND and NST & ND and NST \\
\hline Group 2 & $3000 \mathrm{mg} / \mathrm{kg}$ & ND and NST & ND and NST & ND and NST \\
\hline Group 3 & $4000 \mathrm{mg} / \mathrm{kg}$ & ND and NST & ND and NST & ND and NST \\
\hline Group 4 & $5000 \mathrm{mg} / \mathrm{kg}$ & ND and NST & ND and NST & ND and NST \\
\hline
\end{tabular}

Key: ND =No Death; NST=No Signs of Toxicity 
Table 2: Showing effects of ciprofloxacin-cholate complex and ciprofloxacin on packed cell volume (PCV) of albino mice

\begin{tabular}{|c|c|c|c|c|c|c|}
\hline \multirow[t]{2}{*}{ Group } & \multicolumn{6}{|c|}{ Packed cell volume (\%) } \\
\hline & Pre-administration & $\begin{array}{l}\text { \% } \\
\text { Baseline }\end{array}$ & Day $14^{\text {th }}$ & $\begin{array}{l}\% \\
\text { baseline }\end{array}$ & Post-administration & $\begin{array}{l}\% \\
\text { Baseline }\end{array}$ \\
\hline Complex,21.40 mg/kg & $40.00 \pm 1.63$ & 100 & $41.00 \pm 1.41$ & 102 & $38.75 \pm 0.96$ & 97 \\
\hline Complex,7.14 mg/kg & $41.75 \pm 0.96$ & 100 & $43.25 \pm 0.96^{\mathrm{d}}$ & 108 & $40.00 \pm 1.41$ & 100 \\
\hline Cipro,7.14 mg/kg & $41.00 \pm 1.41$ & 100 & $39.75 \pm 2.50$ & 97 & $39.50 \pm 1.29$ & 96 \\
\hline Control: Distilled water, $10 \mathrm{ml} / \mathrm{kg}$ & $40.50 \pm 1.26$ & 100 & $40.00 \pm 2.16$ & 99 & $40.25 \pm 3.10$ & 99 \\
\hline
\end{tabular}

Values were expressed as mean \pm Standard Deviation $(S D)$ of sample replicate, $n=4$. Pre-administration, Day $14^{\text {th }}$ and Post-administration are significantly different at $\mathrm{p}<0.05$.

Table 3: Showing effects of ciprofloxacin-cholate complex and ciprofloxacin on red blood cell of albino mice

\begin{tabular}{|c|c|c|c|c|c|c|}
\hline \multirow[t]{2}{*}{ Group } & \multicolumn{6}{|c|}{ Red blood cell count (Cell count $\times 10^{12} /$ ) } \\
\hline & Pre-administration & \% baseline & Day 14 ${ }^{\text {th }}$ & \% baseline & Post-administration & \% baseline \\
\hline Complex $21.40 \mathrm{mg} / \mathrm{kg}$ & $10.37 \pm 0.09$ & 100 & $10.55 \pm 1.90$ & 102 & $8.99 \pm 0.65^{\mathrm{d}}$ & 87 \\
\hline Complex, $7.14 \mathrm{mg} / \mathrm{kg}$ & $10.35 \pm 0.74$ & 100 & $10.15 \pm 0.37$ & 98 & $9.59 \pm 0.55$ & 93 \\
\hline Cipro, $7.14 \mathrm{mg} / \mathrm{kg}$ & $10.41 \pm 0.08$ & 100 & $10.24 \pm 0.22$ & 98 & $9.83 \pm 0.42$ & 94 \\
\hline Control: Distilled water, $10 \mathrm{ml} / \mathrm{kg}$ & $10.64 \pm 0.15$ & 100 & $10.65 \pm 0.25$ & 100 & $10.53 \pm 0.19$ & 99 \\
\hline
\end{tabular}

Values were expressed as mean \pm Standard Deviation (SD) of sample replicate, $n=4 .{ }^{d}$ denotes: significantly different from pre-treatment at $p<0.05$. We used a human dose of $500 \mathrm{mg} / \mathrm{kg} \times 2$ in pharmacokinetic because it is a standard practice ant it is accepted in such treatments; and this gives $7.14 \times 2 \mathrm{mg} / \mathrm{kg}$.

Table 4: Showing effects of ciprofloxacin-cholate complex and ciprofloxacin on haemoglobin

\begin{tabular}{|c|c|c|c|c|c|c|}
\hline \multicolumn{7}{|l|}{ Haemoglobin (g/dl) } \\
\hline Group & $\begin{array}{l}\text { Pre- } \\
\text { Administration }\end{array}$ & $\begin{array}{l}\% \\
\text { Baseline }\end{array}$ & Day $14^{\text {th }}$ & $\begin{array}{l}\% \\
\text { baseline }\end{array}$ & Post-administration & $\begin{array}{l}\% \\
\text { Baseline }\end{array}$ \\
\hline Complex $21.40 \mathrm{mg} / \mathrm{kg}$ & $12.85 \pm 0.68$ & 100 & $12.83 \pm 0.30$ & 100 & $13.38 \pm 0.89$ & 104 \\
\hline Complex, $7.14 \mathrm{mg} / \mathrm{kg}$ & $13.35 \pm 0.79$ & 100 & $13.18 \pm 0.75$ & 99 & $13.30 \pm 1.46$ & 100 \\
\hline Cipro, $7.14 \mathrm{mg} / \mathrm{kg}$ & $12.33 \pm 1.36$ & 100 & $13.65 \pm 0.73$ & 111 & $13.05 \pm 0.79$ & 106 \\
\hline Control: Distilled water, $10 \mathrm{ml} / \mathrm{kg}$ & $13.23 \pm 0.51$ & 100 & $13.13 \pm 0.71$ & 99 & $13.08 \pm 1.04$ & 99 \\
\hline
\end{tabular}

Values were expressed as mean \pm Standard Deviation (SD) of sample replicate, $n=4$. Pre-administration, Day $14^{\text {th }}$ and Post-administration are not significantly different at $\mathrm{p}<0.05$.

Table 5: Showing effects of ciprofloxacin-cholate complex and ciprofloxacin on white Blood cell count (WBC) of albino mice

\begin{tabular}{|c|c|c|c|c|c|c|}
\hline \multirow[b]{2}{*}{ Group } & \multicolumn{6}{|c|}{ White blood cell $\left(\times 10^{9} / \mathrm{l}\right)$} \\
\hline & Pre-administration & $\begin{array}{l}\text { \% } \\
\text { Baseline }\end{array}$ & Day $14^{\text {th }}$ & $\begin{array}{l}\% \\
\text { Baseline }\end{array}$ & Post-administration & $\begin{array}{l}\% \\
\text { Baseline }\end{array}$ \\
\hline Complex $21.40 \mathrm{mg} / \mathrm{kg}$ & $8212.50 \pm 746.52$ & 100 & $8962.50 \pm 453.46$ & 109 & $9182.50 \pm 299.82$ & 112 \\
\hline Complex, 7.14 mg/kg & $8100.00 \pm 915.61$ & 100 & $8525.00 \pm 614.41$ & 105 & $9412.50 \pm 359.11$ & 116 \\
\hline Cipro, $7.14 \mathrm{mg} / \mathrm{kg}$ & $8175.00 \pm 698.21$ & 100 & $9087.50 \pm 466.15$ & 111 & $8687.50 \pm 417.08$ & 106 \\
\hline $\begin{array}{l}\text { Control: Distilled water } \\
(10 \mathrm{ml} / \mathrm{kg})\end{array}$ & $8037.50 \pm 290.38$ & 100 & $8000.00 \pm 376.39$ & 100 & $8037.50 \pm 290.38$ & 100 \\
\hline
\end{tabular}

Values are expressed as mean \pm Standard Deviation (SD) of sample replicate, $\mathrm{n}=4$. Pre-administration, Day $14^{\text {th }}$ and Post-administration are not significantly different at $\mathrm{p}<0.05$.

Table 6: Showing effects of ciprofloxacin-cholate complex and ciprofloxacin on alanine aminotransferase (ALT) of albino mice

\begin{tabular}{|c|c|c|c|c|c|c|}
\hline & Amino-transferase & & & & & \\
\hline Group & Pre-administration & $\begin{array}{l}\% \\
\text { Baseline }\end{array}$ & Day $14^{\text {th }}$ & $\begin{array}{l}\% \\
\text { baseline }\end{array}$ & Post-administration & $\begin{array}{l}\% \\
\text { Baseline }\end{array}$ \\
\hline Complex $21.40 \mathrm{mg} / \mathrm{kg}$ & $45.50 \pm 4.20$ & 100 & $50.75 \pm 2.50$ & 112 & $44.50 \pm 4.80$ & 98 \\
\hline Complex, $7.14 \mathrm{mg} / \mathrm{kg}$ & $49.75 \pm 6.85$ & 100 & $52.00 \pm 1.83$ & 105 & $52.00 \pm 1.83$ & 105 \\
\hline Cipro,7.14 mg/kg & $40.25 \pm 1.26$ & 100 & $41.50 \pm 1.29^{d}$ & 103 & $45.75 \pm 3.86^{\mathrm{d}}$ & 114 \\
\hline $\begin{array}{l}\text { Control: Distilled water, } \\
10 \mathrm{ml} / \mathrm{kg}\end{array}$ & $49.75 \pm 0.85$ & 100 & $49.00 \pm 1.04$ & 99 & $49.75 \pm 0.85$ & 100 \\
\hline
\end{tabular}

Values were expressed as mean \pm Standard Deviation (SD) of sample replicate, $\mathrm{n}=4$., ${ }^{\mathrm{d}}$ denotes significantly different from pre-administration at $\mathrm{p}<0.05$

\section{DISCUSSION}

The toxicity studies on the ciprofloxacin-cholate complex showed that the complex was not toxic $5000 \mathrm{mg} / \mathrm{kg}$ body weight of the experimental animal, as there was no death and no signs of toxicity at $5000 \mathrm{mg} / \mathrm{kg}$. From table 2 , there was no significant difference $(\mathrm{P}<0.05)$ in average packed cell volume $(\mathrm{PCV})$ among group means except in Day 14 of $7.14 \mathrm{mg} / \mathrm{kg}$ in which case the complex showed a significant increase $(\mathrm{P}<0.05)$. In addition, average PCV of post-administration did not significantly differ 
from pre-administration in all groups. However, from table 3 , there was no significant difference $(\mathrm{P}<0.05)$ in average red blood cells among group means except in post-administration (relative to pre-administration) in $21.40 \mathrm{mg} / \mathrm{kg}$ complex group. Reduction in the red blood cells could be as a result of many factors that include: anaemia, bone marrow failure, nutritional deficiencies, malnutrition, hemolysis due to blood vessel injury and certain chemotherapy.

Table 7: Showing effects of ciprofloxacin-cholate complex and ciprofloxacin on aspartate aminotransferase (AST) of albino mice

\begin{tabular}{|c|c|c|c|c|c|c|}
\hline & $\operatorname{AST}(\mu / \mathbf{l})$ & & & & & \\
\hline Group & Pre-administration & $\begin{array}{l}\text { \% } \\
\text { Baseline }\end{array}$ & Day $14^{\text {th }}$ & $\begin{array}{l}\text { \% } \\
\text { Baseline }\end{array}$ & Post-administration & $\begin{array}{l}\text { \% } \\
\text { Baseline }\end{array}$ \\
\hline Complex $21.40 \mathrm{mg} / \mathrm{kg}$ & $66.75 \pm 4.57$ & 100 & $61.00 \pm 1.83$ & 91 & $58.00 \pm 4.32^{\mathrm{d}}$ & 87 \\
\hline Complex, 7.14 mg/kg & $66.25 \pm 2.63$ & 100 & $60.50 \pm 6.81$ & 91 & $60.00 \pm 2.50^{\mathrm{d}}$ & 91 \\
\hline Cipro, $7.14 \mathrm{mg} / \mathrm{kg}$ & $61.00 \pm 2.16$ & 100 & $57.75 \pm 2.63$ & 95 & $61.00 \pm 3.56$ & 100 \\
\hline Control: Distilled water, $10 \mathrm{ml} / \mathrm{kg}$ & $65.00 \pm 1.47$ & 100 & $65.00 \pm 1.02$ & 100 & $65.75 \pm 1.74$ & 101 \\
\hline
\end{tabular}

Values were expressed as mean \pm Standard Deviation (SD) of sample replicate, $\mathrm{n}=4$., ${ }^{\mathrm{d}}$ denotes significantly different from pre-administration at $\mathrm{p}<0.05$.

Table 8: Showing effects of ciprofloxacin-cholate complex and ciprofloxacin on alkaline phosphatase (ALP) of albino mice

\begin{tabular}{|c|c|c|c|c|c|c|}
\hline \multirow[b]{2}{*}{ Group } & \multicolumn{6}{|c|}{ Alkaline Phosphate $(\mu / \mathrm{l})$} \\
\hline & Pre-Administration & $\begin{array}{l}\text { \% } \\
\text { Baseline }\end{array}$ & Day 14th & $\begin{array}{l}\% \\
\text { Baseline }\end{array}$ & Post-Administration & $\begin{array}{l}\% \\
\text { Baseline }\end{array}$ \\
\hline Complex $21.40 \mathrm{mg} / \mathrm{kg}$ & $80.50 \pm 1.29$ & 100 & $84.00 \pm 3.65$ & 104 & $77.25 \pm 5.50$ & 96 \\
\hline Complex, 7.14 mg/kg & $79.50 \pm 5.92$ & 100 & $81.00 \pm 3.56$ & 102 & $78.25 \pm 6.55$ & 102 \\
\hline Cipro, $7.14 \mathrm{mg} / \mathrm{kg}$ & $75.75 \pm 5.12$ & 100 & $79.75 \pm 6.55$ & 98 & $77.25 \pm 4.86$ & 102 \\
\hline Control: Distilled water, $10 \mathrm{ml} / \mathrm{kg}$ & $77.00 \pm 2.04$ & 100 & $77.50 \pm 4.36$ & 99 & $77.25 \pm 4.86$ & 100 \\
\hline
\end{tabular}

Values were expressed as mean \pm Standard error of mean (SEM) of sample replicate $(n=4)$. Pre-administration, Day $14^{\text {th }}$ and Post-administration are not significantly different at $\mathrm{p}<0.05$.

Table 9: Serum concentration in $(\mu \mathrm{g} / \mathrm{ml})$ of ciprofloxacin (cipro), ciprofloxacin-cholate complex and PEG-complex in rat

\begin{tabular}{lllllll}
\hline Parameter & $\begin{array}{l}\text { Cipro (7.14 } \\
\mathbf{m g} / \mathbf{k g})\end{array}$ & $\begin{array}{l}\text { Cipro (14.2 } \\
\mathbf{m g} / \mathbf{k g})\end{array}$ & $\begin{array}{l}\text { Complex } \\
\mathbf{( 7 . 1 4} \mathbf{~ m g} / \mathbf{k g})\end{array}$ & $\begin{array}{l}\text { Complex (14.2 } \\
\mathbf{m g} / \mathbf{k g})\end{array}$ & $\begin{array}{l}\text { Complex+PEG 7.14 } \\
\mathbf{m g} / \mathbf{k g}\end{array}$ & $\begin{array}{l}\text { Complex+PEG(14.2 } \\
\mathbf{m g} / \mathbf{k g})\end{array}$ \\
\hline Tmax $(\mathrm{h})$ & $0.63 \pm 0.13$ & $0.50 \pm 0$ & $0 \pm 0^{\mathrm{a}}$ & $0.63 \pm 0.13$ & $0.75 \pm 0.14^{\mathrm{c}}$ & $0.5 \pm 0$ \\
$\mathrm{Cmax}(\mu \mathrm{g} / \mathrm{ml})$ & $1.46 \pm 0.05$ & $1.79 \pm 0.15$ & $0 \pm 0$ & $1.69 \pm 0.05$ & $1.84 \pm 0.04^{\mathrm{c}}$ & $1.91 \pm 0.04$ \\
$\mathrm{AUC}(\mathrm{mg} / \mathrm{ml})$ & $2.38 \pm 0.06$ & $2.81 \pm 0.16$ & $0 \pm 0^{\mathrm{a}}$ & $2.44 \pm 0.11$ & $2.9 \pm 0.09$ & $2.45 \pm 0.34$ \\
$\mathrm{t}_{1 / 2}(\mathrm{~h})$ & $7.85 \pm 2.77$ & $7.07 \pm 1.48$ & $0 \pm 0$ & $4.44 \pm 0.69^{\mathrm{b}}$ & $5.98 \pm 2.80$ & $6.24 \pm 2.32$ \\
$\mathrm{~V}_{\mathrm{d}(\mathrm{mll})} \mathrm{V} \mathrm{V}_{\mathrm{o}}(\mathrm{ml})$ & $6.27 \pm 2.80$ & $20.22 \pm 1.46$ & $0 \pm 0$ & $6.20 \pm 2.09^{\mathrm{b}}$ & $4.51 \pm 1.52$ & $18 \pm 0.64$ \\
$\mathrm{CL}(\mathrm{ml} / \mathrm{kg} / \mathrm{h})$ & $0.24 \pm 0.08$ & $2.16 \pm 0.29$ & $0 \pm 0$ & $0.48 \pm 0.28^{\mathrm{b}}$ & $0.47 \pm 0.19$ & $2.70 \pm 0.69$ \\
MRT $(\mathrm{h})$ & $1.12 \pm 0.01$ & $1.11 \pm 0.01$ & $0 \pm 0^{\mathrm{a}}$ & $1.1 \pm 0$ & $1.1 \pm 0$ & $1.1 \pm 0.01$ \\
\hline
\end{tabular}

Values are represented in mean \pm SEM and Values are expressed as sample replicate $(\mathrm{n}=4)$, aP denotes significantly different from cipro $(7.14 \mathrm{mg} / \mathrm{kg})$ at $\mathrm{P}<0.05$, ${ }^{\mathrm{P}}$ denotes significantly different from cipro $(14.2 \mathrm{mg} / \mathrm{kg})$ at $\mathrm{P}<0.05, \mathrm{c}$ denotes significantly different from cipro $(7.14 \mathrm{mg} / \mathrm{kg})$ at $\mathrm{P}<0.05$

CIPRO is ciprofloxacin; COMPLEX is Ciprofloxacin-cholate complex, COMPLEX+PEG is ciprofloxacin-complex with polyethylene glycol. Tmax is time taken for the drug to attain maximal plasma concentration. Cmax is maximal drug plasma concentration. AUC is area under the curve from the time of dosing to the time of the last observation. $t_{1 / 2}$ is terminal half-life. $C L$ is total clearance and MRT is the mean residence time.

High red blood count is an indicative of dehydration, bone marrow or other health disorders. The significant decrease in the average RBCs count in post-treatment of $21.47 \mathrm{mg} / \mathrm{kg}$ of the complex could be as a result of physiological changes. Table 4 showed that there was no significant difference $(\mathrm{P}<0.05)$ in average haemoglobin among group means on day 14; average haemoglobin of postadministration did not significantly differ from pre-administration and vice versa in all groups. Haemoglobin transports oxygen and gives the blood cell its red colour. Its concentration is directly proportional to its ability to transport oxygen throughout the body. So, non-significant difference at $(\mathrm{P}<0.05)$ in average haemoglobin among groups was indicative of sufficient oxygen. Thus the drug did not interfere with oxygen supply throughout the body. From table 5, there was no significant increase or decrease in average WBC count.

However, average WBC of $7.14 \mathrm{mg} / \mathrm{kg}$ and 21.40 of the complex in post-administration increased relative to pre-administration, though not significant. In addition, there was a non-significant increase in day 140 f $7.14 \mathrm{mg} / \mathrm{kg}$ of ciprofloxacin. White blood cells (Leukocytes) are an important part of the body's defense against infectious organism and foreign substances. The non-significant decrease in the white blood cell is an indication that ciprofloxacin and its complex are not immunosuppressant. From table 6, there was a significant increase in average ALT level in post-administration Day 14 relative to pre-administration $(\mathrm{P}<0.05)$ in ciprofloxacin group. ALT is present in high concentration in the cytosol of the liver and to a lesser extent in skeletal muscle, kidney and heart [12]. Serum ALT activity has been regarded as a reliable and sensitive marker of liver disease. When there is an increase in ALT viral or drug-induced hepatitis will be suspected. In addition, ALT may also be a good indicator of overall health such as obesity, the metabolic syndrome, and presence of cardiovascular disease [13]. The non-significant increase in average ALT level in $7.14 \mathrm{mg} / \mathrm{kg}$ and $21.4 \mathrm{mg} / \mathrm{kg}$ of the complex suggests the absence of hepatocellular damage and another health disease. However, our result showed a significant increase in average ALT at post administration and day 14 th of $7.14 \mathrm{mg} / \mathrm{kg}$ ciprofloxacin group. Thus suggesting indicated a major liver permeability, congestion and cell rupture in ciprofloxacin group [14]. This result agrees with the findings of Pyriyadharshiri and Vanithakumari [15] that ciprofloxacin could exert a mild or high effect on ALT level in the serum when administered for a short or long duration. They also showed that enzymatic activity (ALT level) varies in a dose-dependent manner. From table 7 , there was a significant decrease $(\mathrm{dP}<0.05)$ in Post-administration onDay 14 of 
average AST relative to Pre-administration AST in $7.14 \mathrm{mg} / \mathrm{kg}$ and $21.40 \mathrm{mg} / \mathrm{kg}$ complex group respectively. AST is an enzyme present in the liver, nervous tissue, skeletal muscle, and heart. Membrane damages release this enzyme into circulation. High level is indicative of liver damage due to toxicity and viral hepatitis as well as cardiac infection and muscle injury [16]. Ciprofloxacin and its cholatecomplex did not have a significant increase in serum AST compared with pre-administration. This suggested that the integrity of the cell membranes of various tissues (especially the heart and liver) were not adversely affected. This result supports the findings of Obaleye and co-workers [17].

From table 8, there was no significant difference $(\mathrm{P}<0.05)$ in average ALP level among group means on day 14. Average ALP of postadministration did not significantly differ from pre-administration and verse versa in all groups. The fact that there was no significant difference in serum ALP activities of Ciprofloxacin and its cholatecomplexes suggests that the integrity of the plasma membrane of the cells in the various tissues (bone, liver and kidney) might not have been adversely affected. This is because ALP is a membrane-bound enzyme often used to assess the integrity of the plasma membrane and endoplasmic reticulum. An increase in ALP activity of the serum implies membrane damage to the tissue [18].

Also, there was a significant difference $(\mathrm{d}<0.05)$ in average albumin among group means on post-administration of $21.40 \mathrm{mg} / \mathrm{kg}$ complex. Average albumin level of post-administration of 21.40 $\mathrm{mg} / \mathrm{kg}$ complex significantly decreased when compared with Day 14. Albumin reduction suggests liver disease, kidney disease or low protein absorption [19]. However, results of ALT, AST and ALP had shown no significant increase, hence, the significant decrease of albumin level at $21.40 \mathrm{mg} / \mathrm{kg}$ of the complex may be attributed to a slight side effect of high dose of the complex.

In the histopathology, experimental groups 1, 2, 3 and 4 (control) were administered with $21.40 \mathrm{mg} / \mathrm{kg}$ of complex, $7.14 \mathrm{mg} / \mathrm{kg}$ of complex, $7.14 \mathrm{mg} / \mathrm{kg}$ of ciprofloxacin and $10 \mathrm{mg} / \mathrm{ml}$ of water respectively, for two weeks. Results showed that ciprofloxacin at dose $7.14 \mathrm{mg} / \mathrm{kg}$ and ciprofloxacin-cholate complex at dose 21.4 $\mathrm{mg} / \mathrm{kg}$ induced hepatocellular degeneration (white arrows) and mononuclear cell infiltration an inflammatory reaction of the lymphocytes and the plasma cell, (black arrows) both of which are reversible. Group 2 and the control were apparently normal (fig. 1).

The pharmacokinetics analysis showed that the complex was not detectable in the serum at $7.14 \mathrm{mg} / \mathrm{kg}$. This might stem from the fact that the percentage content of CIPRO (44.9\%) in $500 \mathrm{mg}$ of the complex was small. In our study, pharmacokinetics parameter of $14.2 \mathrm{mg} / \mathrm{kg}$ of CIPRO when compared to $14.2 \mathrm{mg} / \mathrm{kg}$ of complex showed that the complex at this dose increased the $t_{\max }$ from $0.5 \mathrm{~h}$ to $0.63 \mathrm{hr}$ (table 9). This showed a longer time of absorption, though it was negligible. The $C_{\max }$ decreased from $1.79 \mu \mathrm{g} / \mathrm{ml}$ to $1.69 \mu \mathrm{g} / \mathrm{ml}$ and AUC from $2.8 \mathrm{mg} / \mathrm{ml}$ to $2.44 \mathrm{mg} / \mathrm{ml}$, showing non-significant increases of $5.59 \%$ and $12.9 \%$ respectively. The decreases in the two parameters were indicative of poor absorption and poor systemic availability of the drug complex, which may affect its therapeutic efficacy [20]. Although the mean resident time of the complex remained unchanged, the half-life decreased from $7.85 \mathrm{hr}$ to $4.44 \mathrm{~h}(43.4 \%)$, while clearance rate changed from $2.16 \mathrm{ml} / \mathrm{kg} / \mathrm{h}$ to $0.47 \mathrm{ml} / \mathrm{kg} / \mathrm{h}$; theoretically, ciprofloxacin half-life ranges from 3-4 h. The decrease in half-life showed that the complex did not stay longer in the blood, while the decrease in clearance rate may be indicative of low metabolizing activity by cytochrome $\mathrm{P}_{450}$ enzymes in the liver [21]. The significant decrease in $V_{0}$ may be indicative of more complex binding to the plasma protein rather than to the tissue [22].

The $7.14 \mathrm{mg} / \mathrm{kg}$ CIPRO compared to $7.14 \mathrm{mg} / \mathrm{kg}$ complex+PEG showed that $7.14 \mathrm{mg} / \mathrm{kg}$ increased the $\mathrm{C}_{\max }$ from $1.46 \mu \mathrm{g} / \mathrm{ml}$ to 1.84 $\mu \mathrm{g} / \mathrm{ml}$ and AUC from $2.38 \mathrm{mg} / \mathrm{ml}$ to $2.9 \mathrm{mg} / \mathrm{ml}$. Since $C_{\max }$ and AUC are biomarkers for bioavailability [23], an increase in the two parameters is indicative of an enhanced absorption and good systemic availability. Also, there was an increase in clearance rate from $0.24 \mathrm{ml} / \mathrm{kg} / \mathrm{h}$ to $0.47 \mathrm{ml} / \mathrm{kg} / \mathrm{h}$ while the MRT remained unchanged. This showed a high metabolizing activity of cytochrome $\mathrm{P}_{450}$ enzyme in the liver [21]. The decrease in $\mathrm{V}_{0}(-1.56)$ is not far from its high plasma protein binding [24]. On the same hand, 14.2 $\mathrm{mg} / \mathrm{kg}$ CIPRO compared to complex+PEG at $14.2 \mathrm{mg} / \mathrm{kg}$ showed that $t_{\max }$ was constant $\left(0.5 \mathrm{~h}\right.$ ), and there was an increase in $\mathrm{C}_{\max }$ (from $1.79 \mu \mathrm{g} / \mathrm{ml}$ to $1.91 \mu \mathrm{g} / \mathrm{ml}$ ). This showed enhanced absorption and good systemic availability possibly as a result of the effect of polyethylene glycol on the drug, however, the AUC decreased nonsignificantly. Although the half-life decreased from $7.8 \mathrm{~h}$ to $6.2 \mathrm{~h}$ ( $20.5 \%$ ), clearance rate increased from $2.16 \mathrm{ml} / \mathrm{kg} / \mathrm{h}$ to $2.7 \mathrm{ml} / \mathrm{kg} / \mathrm{h}$ along with an unchanged MRT. This result suggested a metabolic activity catalyzed by cytochrome $\mathrm{P}_{450}$ resident in the liver. The decrease in $V_{0}$ from $20.22 \mathrm{ml}$ to $18 \mathrm{ml}(-2.22 \mathrm{ml})$ indicated a slight plasma protein-binding [24].

The complex at $7.14 \mathrm{mg} / \mathrm{kg}$ was detected in the serum upon addition of polyethylene glycol, which indicated an improved systemic availability of the complex at this dose. Also, the dosage of 14.2 $\mathrm{mg} / \mathrm{kg}$ showed an improved systemic availability with polyethylene glycol, though there was an increase in clearance and reduction in the half-life of the drug. The mean resident time was found to have little or no change while the volume of distribution showed a high protein binding. All these results have shown that ciprofloxacincholate complex with reduced percentage of ciprofloxacin (44.9\%) has improved bioavailability thus effective therapeutic efficacy, although with the assistance of polyethylene glycol.

\section{Ethical approval}

All authors hereby declare that the principles of laboratory animal care "(NIH publication No 85-23, revised 1985) [8], were adopted, and experiments were examined and approved by the appropriate ethics committee" of the Faculty (Faculty of Pharmaceutical Sciences, Nnamdi Azikiwe University, Awka).

\section{CONCLUSION}

The $\mathrm{LD}_{50}$ of the complex was above $5000 \mathrm{mg} / \mathrm{kg}$. The biochemical, hematological and histology results showed that complexation did not increase adverse effects of ciprofloxacin and that any such slight effects were reversible upon discontinuation of administration. The PEGYlated complex showed higher AUC peak and residence time than the uncomplexed drug. Thus, we could conclude that the PEGYlated complex would be therapeutically more beneficial than the uncomplexed drug.

\section{ACKNOWLEDGMENT}

We are indebted to the following people: Prof. Edward C. Nwanegbo of the Department of Surgery, University of Pittsburgh, Prof. Ralf Stahlmann of the Institute for Clinical Pharmacology and Toxicology, Germany and distinguished lecturers of the Faculty of Pharmaceutical Sciences, Nnamdi Azikiwe University, Nigeria for their wonderful contributions and encouragement. Dr B. O. Onoja of the Department of Veterinary Anatomy, University of Agriculture, Makurdi, is also acknowledged for his advice; Pharmacist Dr. S. O. Nduka, Mr E. Ajaegbu, Dr. D. L. Ajaghaku and Mr. T. Gugu are immensely appreciated for their technical assistance.

\section{CONFLICT OF INTERESTS}

This research work titled 'Pharmacokinetics, Hematological and Biochemical Effects of Ciprofloxacin hydrochloride-Sodium cholate Complex' was carried out by Dr. Osonwa U. E., Mrs. Ugochukwu J. I., Dr. Onyegbule F. A. and Professor Esimone C. O.

The work has not been submitted elsewhere for consideration for publication. It is submitted for consideration for publication in your Journal, Drug Metabolism and Pharmacokinetics, with the consent of all the authors, with no disagreement. There is no conflict of interest amongst the authors of this research manuscript.

\section{REFERENCES}

1. Chin NX, Neu HC. Ciprofloxacin a quinolone carboxylic acid compound active against aerobic and anaerobic bacteria. Antimicrob Agents Chemother 1984;25:319-26.

2. Santos L, Rodrigues D, Lira M, Oliveira R, Oliveira M, Vilar E, et al. The effect of octylglucoside and sodium cholate in Staphylococcus epidermidis and pseudomonas aeroginosa 
adhesion to soft contact lenses. Am Acad Optom Vis Sci 2007;84:429-34.

3. Adikwu E, Brambaika N. Toxicological effect of ciprofloxacin on testicular function of male Guinea pigs. J Exp Biol Sci 2012;3:384-90.

4. Arash KDVM, Heidari M, Novin MC, Afshin KA. Adverse effects of ciprofloxacin on testis apoptosis and sperm parameters in rats. J Reprod Med 2008;6:71-6.

5. Veronese FM, Pasut G. PEGylated, successful approach to drug delivery. J Drug Discovery Today 2005;10:1452-6.

6. Abuchowski A, Davis FF. Effect of covalent attachment of polyethylene glycol on immunogenicity and circulating life of bovine liver catalase. J Biochem 1977;252:3582-6.

7. Lork D. A new approach for acute toxicity testing. Arch Toxicol 1983;58:275-87.

8. Guide for the Care and Use of Laboratory Animals. NIH Publication; 1985. p. 85-23.

9. Dacie JV, Lewis SM. Practical hematology. 9th Edition Churchill Livingstone; 2000.

10. Reitman S, Frankel S. In vitro determination of transaminase activity in serum. Am J Clin Pathol 1975;28:56-8.

11. Klein B, Read PA, Babson LA. In vitro determination of alkaline phosphate in serum or plasma. Clin Chem 1960;6:269-75.

12. Zilva JF, Pannel P, Mayne PD. The plasma enzyme in diagnosis. In: Clinical chemistry in diagnosis and treatment. PG publishing PVT. Ltd, India; 1991.

13. Kundrotas LW, Clement DJ. Serum alanine aminotransferase (ALT) elevation in asymptomatic US air force basic trainee blood donor. Dig Dis Sci 1993;38:2145-50.

14. Pieme CA, Penlap VN, Nkegoum B, Taziebou CL, Tekwu EM, Etoa FX, et al. Evaluation of acute and subacute toxicities of an aqueous ethanolic extract of leaves of Senna alata (L) Roxb (ceasalpiniaceae). Afr J Biotechnol 2008;5:288-9.
15. Pyriyadharshiri KM, Vanithakumari GV. Ciprofloxacin-induced body weight and serum biochemical changes in rats and antioxidant vitamin $\mathrm{A}, \mathrm{C}$ and $\mathrm{E}$ as rescue agents. Int J Eng Sci 2013;4:1211-3.

16. Varley H, Gowenlock AH, Bell M. Practical clinical biochemistry. 5th edition. CBS Publishers and Distributors, India; 1991.

17. Obaleye JA, Akinremi CA, Balogun EA, Adebayo JO. Toxicological studies and antimicrobial properties of some iron (III) complexes of ciprofloxacin. Afr J Biotechnol 2007;6:2826-32.

18. Akanji MA, Olagoke OA, Oloyede OB. Effects of chronic consumption of metabisulphite on the integrity of the rat kidney cellular system. J Toxicol 1993;81:173-9.

19. Mutlu EA, Keshavarzian A, Mutlu GM. Hypoalbuminemia elevated transaminase associated with diet. J Gastrol 2006;41:759-60.

20. Tando V. Pharmacokinetics in drug discovery and development. Florida. C. R. C Press; 2002.

21. Mizuki Y, Fujiwara I, Yamaguch T. Pharmacokinetics interactions related to the chemical structures of fluoroquinolones. J Antimicrob Chemother 1996;37:41-55.

22. Nduka SO, Okonta JM, Esimone CO. In vivo evaluation of the effects of Allium sativum on the pharmacokinetic parameters of ciprofloxacin and Isoniazid. Int J Drug Discovery 2012;4:123-7.

23. Jambhekar SS, Breen PJ. Basic pharmaceutics: extravascular routes of drug administration. Pharmaceutical Press: London; 2009. p. 101.

24. Sorgel F, Kinzig. Pharmacokinetics of gyrase inhibitors: renal and hepatic elimination pathways and drug interactions. Am J Med 1993;94:56-9.

\section{How to cite this article}

- Osonwa UE, Ugochukwu JI, Onyegbule FA, Esimone CO. Pharmacokinetics, hematological and biochemical effects of ciprofloxacin hydrochloride-sodium cholate complex. Int J Pharm Pharm Sci 2016;8(10):96-101. 